\title{
熱源システム運転支援のための負荷予測の検討
}

\section{Load Prediction for Operation of Heat Supply Systems}

\author{
正 横山 良平 (阪府大院) \\ 正 伊東 弘一（阪府大院） \\ 松葉 匡彦（山武ビルシステム）
○学 西野 㳯 (阪府大院)
神村 一幸（山武ビルシステム）

Ryohei YOKOYAMA, Osaka Prefecture University, 1-1 Gakuen-cho, Sakai, Osaka Atsushi NISHINO, Koichi ITO, Osaka Prefecture University

Kazuyuki KAMIMURA, Tadahiko MATSUBA, Yamatake Building Systems Co., Ltd.

To operate heat supply systems rationally, it is necessary to predict loads accurately and determine the schedule for the on/off status of operation and load allocation of each piece of equipment in the systems appropriately. Several prediction and scheduling methods have been proposed separately. In this paper, a method of identifying an ARIMA prediction model using the nonlinear programming is proposed to make the prediction suitable for the scheduling. Though a case study, it turns out that the method can reduce the variations of predicted loads.

Key Words : Heat Supply Systems, Scheduling, Load Prediction, ARIMA Model, Nonlinear Programming

\section{1. 緒 言}

熱源システムの運転をリアルタイムで支援するために要 求される基本的機能として, 負荷の予測機能と機器の運用 スケジューリング機能が挙げられ, 両機能の統合化が重要 な課題となっている. 負荷予測に関しては、これまで様々 な手法が提案されている. 例えば, 時系列モデルによる方 法では, 統計学的手法によって負荷の実測值と予測値の誤 差を小さくするようにモデル同定が行われている(1). しか しながら, 時々刻々変化する負荷に適応しながら機器の運 用スケジューリングを行うには，上記の誤差が小さいだけ でなく, 同一被予測時刻における予測値の時間変動も小さ いことが望ましいものと考えられる. 本研究では,これら の点を考慮しながらモデル同定を非線形計画法によって行 う方法を提案し，予測事例によってその有効性を検討する.

\section{2. 負荷予測法}

2.1 予測モデル 本研究では, 予測モデルとして, 次 式で表されるARIMA(Autoregressive Integrated Moving Average)モデルを採用する.

$$
x_{n}-x_{n-s}=\sum_{i=1}^{p} a_{i}\left(x_{n-i}-x_{n-i-s}\right)+e_{n}+\sum_{j=1}^{q} b_{j} e_{n-j}
$$

ここで, $x$ は負荷の実測値, $e$ は負荷の予測誤差, 下付添 字は離散化された時間のステップを表す，s は非定常時系 列の周期に対応するステップ数を表す. $p, q$ は ARIMA モ デルの次数, $a_{i}, b_{j}$ は係数である.

2.2 モテル同定 予測モデルを得るためには, $p, q$, $a_{i}, b_{j}$ の各值を決定する必要がある. ここでは $p, q$ の值が 与えられた時に以下のように $a_{i}, b_{j}$ の値を決定する.

$$
y_{n}=x_{n}-x_{n-s}
$$

とする. 時刻 $n$ までの実測值に基づく $K$ ステップ先までの $y_{n+k}(k=1,2, \cdots, K)$ の予測值を $\tilde{y}_{n+k \mid n}$ とすると, 式(1)より

$$
\tilde{y}_{n+k j n}= \begin{cases}\sum_{i=1}^{p} a_{i} y_{n+k-i}+\sum_{j=1}^{q} b_{j} e_{n+k-j} & (k=1) \\ \sum_{i=1}^{k-1} a_{i} \tilde{y}_{n+k-i+n}+\sum_{i=k}^{p} a_{i} y_{n+k-i}+\sum_{j=k}^{q} b_{j} e_{n+k-j} & (2 \leq k \leq \min (p, q)) \\ \sum_{i=1}^{p} a_{i} \tilde{y}_{n+k-i \mid n}+\sum_{j=k}^{q} b_{j} e_{n+k-j} & (p<k \leq q)\end{cases}
$$

$$
\mid \begin{array}{ll}
\sum_{i=1}^{k-1} a_{i} \tilde{y}_{n+k-i \mid n}+\sum_{i=k}^{p} a_{i} y_{n+k-i} & (q<k \leq p) \\
\sum_{i=1}^{p} a_{i} \tilde{y}_{n+k-i \mid n} & (\max (p, q)<k)
\end{array}
$$

で表される。ここで，予測誤差 $e_{n}$ は

$$
e_{n}=y_{n}-\tilde{y}_{n \mid n-1}
$$

で表される. ただし, $s \leq n \leq s+\max (p, q)$ の籁用では, $\tilde{y}_{n \mid n-1}$ が評価できないので, $e_{n}=0$ と仮定する.

非線形計画法として一般縮小勾配法を採用し，式(3)を制 約条件とし，目的関数

$$
\sum_{n=s+\max (p, q)}^{N-1}\left(\tilde{y}_{n+1 \mid n}-y_{n+1}\right)^{2}+\sum_{k=2}^{K}\left\{\sum_{n=s+\max (p, q)}^{N-k}\left(\tilde{y}_{n+k \mid n}-\tilde{y}_{n+k \mid n+1}\right)^{2}\right\}
$$

を最小にする $a_{i}, b_{j}$ の值を求める．ただし， $K=1$ のとき は第 2 項を 0 とする.ここで， $N$ は $y_{n}$ のデー夕数を表す. 式(5)の第 1 項は予測值と実測值の誤差の 2 乗和を意味する. 第 2 項は，同一被予測時刻における予測を $k$ ステップ前に 行った值と $(k-1)$ ステップ前に行った値の差の 2 乗和を意 味する. 従来の統計学的手法によるモデル同定では第 1 項 のみが考虑されているが，本同定法では第 2 項を考虑する ことにより予測值の時間変動の小さいモデルを得る.

2.3 负茅測 同定された予測モデルを用いて式(3) によって予測値 $\tilde{y}_{n+k \mid n}$ を求める. また, $n$ における $x_{n+k}$ の予 測值 $\tilde{x}_{n+k \mid n}$ を, 式(2)に基づき

$$
\tilde{x}_{n+k \mid n}=\tilde{y}_{n+k \mid n}+x_{n+k-s}
$$

によって求める.

\section{3. 負荷予測事例}

3.1 予測条件 具体的な予測対象として, 熱角荷予測 公開ベンチマークテストに採用された延床面皘約 $5400 \mathrm{~m}^{2}$, 1 階に駐車スペースを持つ 9 階層の商用ビル全体の 1996 年 9 月における冷熱負荷を取り上げる(2)．9/5 22:00 9/6 23:00, および 9/9 0:00〜9/13 21:00の平日 6 日間の 1 時間 毎の冾熱負荷の実測值を用いて予測モデルの同定を行った。 また，9/13 22:00〜23:00および 9/17 0:00〜21:00の平日 の 1 時間每の冷熱負荷の予測を行った.さらに, 9/17 21:00 までの最新の平日 6 日間のデータを用いて予測モデルを再 同定し，9/17 22:00 23:00 および 9/18 0:00〜21:00の平 日の予測も同様に行った. 9/5 22:00から 9/18 21:00の間 
の平日の冷熱負荷実測値の変動を図 1 に示す.

予測モデル同定時に与える $s, N$ の値として $, s=24, N=$

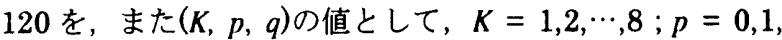
$\cdots, 6 ; q=0,1, \cdots, 6$ の䇶囲のあらゆる組合せを用い, これら の各組合せについて 1 つの予測モデルを得る.ただし, $p=$ 0 かつ $K>q$ の組合せは，式(5)を定義できず，モデル同定 が行えないので，除外した。

次に，上記の予測法との比較対象として用いる，統計学 的手法によりモデル同定を行った ARIMA モデル(以下，従 来法)による予測に関する条件を示す(2)．予測モデル同定時 には，過去の平日 10 日分の 1 時間毎の椧熱負荷の実測値 を用いた。 9/13 21:00 までの実測値に基づき同定を行った モデルで 9/17 21:00 までの予測を,また 9/17 21:00 までの 実測値に基づき同定を行ったモデルで 9/18 21:00までの予 測をそれぞれ行った。

3.2 予測結果および考察予測の評価指標上して, 次 の 2 つの值を用いる.

$$
E=\sqrt{\frac{\sum_{i=1}^{L}\left\{\sum_{n=N}^{N+s-1}\left(\tilde{x}_{n+1 / n}-x_{n+1}\right)^{2}\right\}}{L(s-L / 2+1 / 2)}}
$$

$$
V=\left\{\begin{array}{l}
\sqrt{\frac{\sum_{n=N}^{N+s-1}\left(\tilde{x}_{n+1 \mid n}-x_{n+1}\right)^{2}}{s}} \\
\sqrt{\frac{\sum_{n=N}^{N+s-1}\left(\tilde{x}_{n+1 \mid n}-x_{n+1}\right)^{2}+\sum_{l=2}^{L}\left\{\sum_{n=N}^{N+k-1}\left(\tilde{x}_{n+1 \mid n}-\tilde{x}_{n+1 \mid n+1}\right)^{2}\right\}}{L(s-L / 2+1 / 2)}}
\end{array}\right.
$$

$E$ は $L$ ステップ先までの予測値と実測値の誤差の 2 乗平均 平方根である. $V$ は 1 ステップ先予測值と実測值の誤差と， Lステップ先までの予測值における, lステップ先予測値と $(l-1)$ ステップ先予測値の差との 2 乗平均平方根である.

各予測モデルによる予測結果について $L=6$ として $E, V$ の值を算出した. モデル作成時に与えた $(K, p, q)$ の值と $E$ の值の関係を図 2 に, $(K, p, q)$ の值と $V$ の值の関係を図 3 にそれぞれ示寸．因 2, 図 3 において，横軸は $(K, p, q)$ の組 合せを 3 桁の整数，士なわち，K, $p, q$ の值をそれぞれ百， 十，一の位にもつ整数で表している．また，従来法による 予測結果における $E, V$ の值を表 1 に示す.

提案法により同定した予测モデルの 8 割以上が, 従来法 による予測結果における $E, V$ の値のより小さい $E, V$ の值 を与えることが判った．予測誤差の大きさを表す $E$ の值は

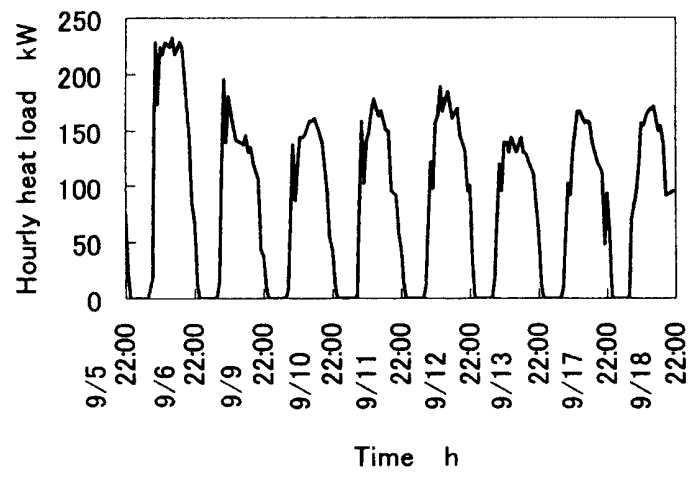

Fig. 1 Load profiles for weekdays
同程度であったが，予測值の時間変動を表す $V$ の值は大幅 に减少することが判った．また，予測モデルを決定するた めには，適切な $(K, p, q)$ の組合せを選択する必要があるが， 計算結果から， $(K, p, q)$ の組合せが $E, V$ の值に与える影響 の傾向が明らかになった。

\section{4. 結 曹}

非線形計画法により ARIMA モデルに基づく予測モデル を同定する方法を提案した．また，熱負荷予測公開ベンチ マークテストに採用された冷熱負荷について提案法により 負荷予測を行い，従来法と比較して誤差が同程度で予測値 の変動が小さい負荷予測を行える可能性があることが判っ た.

\section{文献}

（1）金原・黒須・宮坂・神村，ARIMA モデルによる空調熱負荷 予測，計測自動制御学会論文集，26-6 (1990)，721-728.

（2）筒井・松葉・神村，熱負荷予測ベンチマークテストにおける TCBM+ARIMA ハイブリッドモデルの予測結果報告, 空気 調和・衛生工学会学術講演会講演論文集, (1998), 122-125.

- 9/13 22:00 9/17 21:00

* 9/17 22:00 9/18 21:00

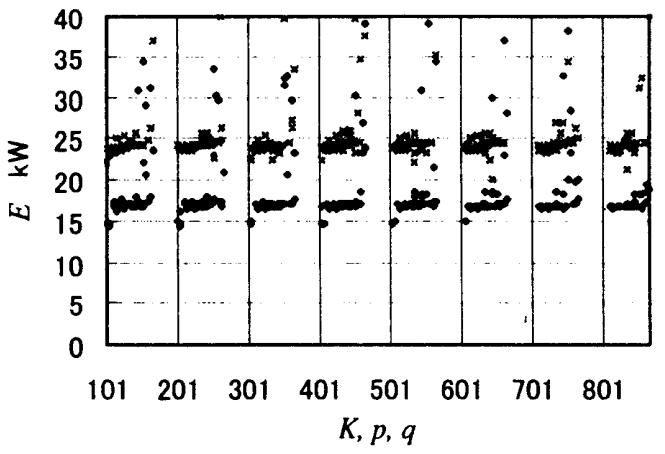

Fig. 2 Relationship between $(K, p, q)$ and $E$

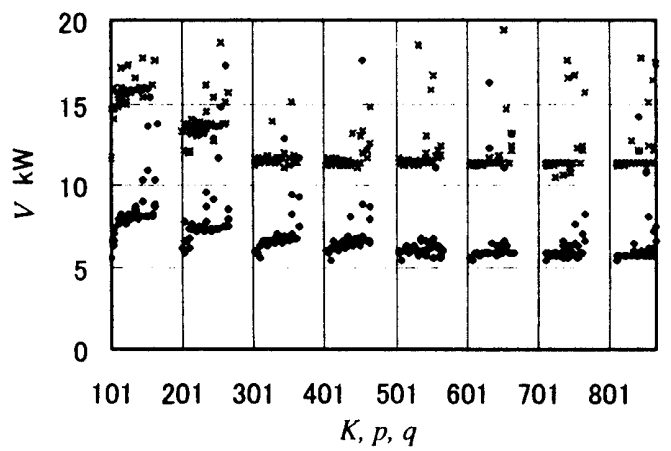

Fig. 3 Relationship between $(K, p, q)$ and $V$

Table 1 Values of $E$ and $V$ for prediction by conventional method

Unit: $\mathrm{kW}$

\begin{tabular}{ccc}
\hline Day & $E$ & $V$ \\
\hline 9/16 22:00 9/17 21:00 & 19.0 & 10.1 \\
9/17 22:00 9/18 21:00 & 26.8 & 21.4 \\
\hline
\end{tabular}

